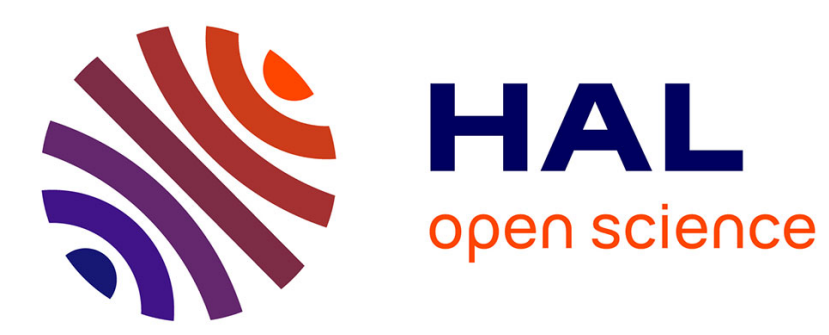

\title{
Cosmetic Surgery on Trial: How the Dujarier Case Impacted its Practice and Structure in France during the Interwar Period
}

Yannick Le Hénaff

\section{- To cite this version:}

Yannick Le Hénaff. Cosmetic Surgery on Trial: How the Dujarier Case Impacted its Practice and Structure in France during the Interwar Period. Social History of Medicine, 2017, 10.1093/shm/hkx054 . hal-01684141

\section{HAL Id: hal-01684141 https://hal.science/hal-01684141}

Submitted on 15 Jan 2018

HAL is a multi-disciplinary open access archive for the deposit and dissemination of scientific research documents, whether they are published or not. The documents may come from teaching and research institutions in France or abroad, or from public or private research centers.
L'archive ouverte pluridisciplinaire HAL, est destinée au dépôt et à la diffusion de documents scientifiques de niveau recherche, publiés ou non, émanant des établissements d'enseignement et de recherche français ou étrangers, des laboratoires publics ou privés. 


\title{
Cosmetic Surgery on Trial: How the Dujarier Case Impacted its Practice and Structure in France during the Interwar Period
}

\author{
Yannick Le Hénaff*
}

\begin{abstract}
Summary. This article aims to shed light on the impact of trials on the structure of cosmetic surgery in France in the interwar period, and more specifically on the argumentative strategy these surgeons used to justify their therapeutic merits. The significant surge in the number of articles and books devoted to cosmetic surgery published during the court hearings reflects the growing professional and social interest in the 'scandalous' practice. Resorting to the reading grid used by pragmatic sociologists is a way to take the surgeons defending or practising cosmetic surgery to their word. The analysis of the stance adopted by the surgeons will be two-fold: they are quite revealing of a way of constraining cosmetic surgery but they also help bring to light what is at stake in the medical arena and what drove doctors to support a denigrated practice.
\end{abstract}

Keywords: Cosmetic surgery; France; Interwar; controversy; trial

'[Cosmetic] surgery remains a valid and beneficial practice, and the sole purpose of some surgeries is to remove the cause of permanent grief that is often ignored even by the patient's relatives. ... Isn't surgery entitled to remove them?' Those are the very words that Léon Dufourmentel used to defend his fellow surgeon Charles Dujarier in an editorial published in Le Figaro on 4 March 1929. At the time, Dujarier was being sued by Suzanne Geoffre, a young patient whose leg had to be amputated after Dujarier conducted cosmetic surgery on her calves. ${ }^{1}$ Affected by ungainly legs and suffering from adipose hyperplasia, Geoffre consulted several doctors before meeting Dujarier. At that time he was considered one of the top French limb specialists. He agreed to conduct the fat removal surgery, even though it was complicated. ${ }^{2}$ After a gripping trial, the court

\footnotetext{
*Université de Rouen, Mont-Saint-Aignan, 76821, FR. yannick.lehenaff@yahoo.fr

Yannick Le Hénaff is a lecturer of sociology of health at Normandy University in Rouen, France. He is interested in the political transformations in the health's world on France. He is working in three main areas: cosmetic surgery, experience of rare disease and alcohol consumption.
}

\footnotetext{
${ }^{1}$ The trial has already been dealt with in two other research studies. See J. Glicenstein, 'L'affaire Dujarier', Annales de chirurgie plastique esthétique, 1989, 34, 290-2. C. W. Comiskey, 'Cosmetic Surgery in Paris in 1926: The Case of the Amputated Leg', Journal of Women's History, 2004, 16, 30-54 and '"I will kill myself. ... If I have to keep my fat calves". Legs and Cosmetic Surgery in Paris in 1926', In C. E.Forth, I. Crozier, eds, Body Parts, Critical Explorations in Corporeality (Lanham: Lexington Books, 2005), 247-63. For a better understanding of cosmetic surgery during this period, see $\mathrm{N}$. Guirimand, 'de la réparation des "gueules cassées" à
}

la "sculpture des visages". La naissance de la chirurgie esthétique en france pendant l'entre-deux-guerres', Actes de la Recherche en Sciences Sociales, 2005, 156-7, 1-2, 72-87 ; P. Martin, 'Suzanne Noël', Cosmetic Surgery, Feminism and Beauty in Early Twentieth-century France (Dorchester: Ashgate, 2014).

${ }^{2}$ Lacking an operative report on the surgery, Glicenstein argues that Dujarier may have executed a 'fusiform excision of the skin and of the subcutaneous fatty tissue on the backside of the leg'. See Glicenstein, 'L'affaire Dujarier', 290. 
ruled against the practitioner, accusing him of negligence. The ruling is also an indictment of cosmetic surgery as a whole, disavowing any claims that the practice held therapeutic merit.

The very fact of having performed an operation that could seriously endanger a healthy limb, with the sole purpose of correcting its shape, and the fact that this surgical procedure was in no way therapeutically necessary and in no way beneficial to the patient's health, are grounds enough to consider this a case of serious professional misconduct for which the surgeon should be held liable. ${ }^{3}$

The repercussions of the court ruling and of the rejection of Dujarier's 1931 appeal on the nascent community of specialists were unprecedented, as was the decision's impact on the greater medical community. It created such an upheaval that the case came to be seen as a political event, which in turn became the cornerstone of a collective professional identity for French cosmetic surgeons. ${ }^{4}$ In addition, because Dujarier's sentencing was such a rallying cry, it brought about the creation of the first, albeit short-lived, French scientific society, the Société Scientifique Française de Chirurgie Réparatrice, Plastique et Esthétique. This article aims to shed light on the impact these trials have had on the world of cosmetic surgery and to demonstrate the way doctors involved in cosmetic surgery conceptualize both their specific field and the practice of medicine as a whole. $^{5}$

In France, the history of cosmetic surgery starts with the surgical innovations required to care for the Gueules Cassées, the First World War veterans who had suffered severe facial injuries. The 10,000-15,000 disfigured soldiers, who were kept alive despite their serious wounds, represented an unprecedented challenge to the medical world; the effort to meet this challenge engendered an entirely new field of medical research. In the heat of the Second World War, scientific research in cosmetic surgery, still in its early stages, came to a temporary halt. ${ }^{6}$ However, the treatment of the severely disfigured soldiers aroused such interest in the medical world that it encouraged practitioners to train to perform a wide range of plastic surgeries. After the war, some of them would apply their surgical knowledge and techniques to cosmetic surgery and thus become the first generation of French doctors involved in cosmetic procedurees. The transition from

\footnotetext{
${ }^{3}$ Extract of the court ruling in E. Saint-Auban, 'La Chirurgie Esthétique', In Revue des grands procès contemporains: recueil d'éloquence judiciaire (Paris: Ed. Emile de Saint-Auban, 1929), 191-227, 226.

${ }^{4}$ References to this legal case remain extremely common even decades after the fact. This demonstrates the importance that these practitioners give to the trial. The following are just a few of many such references: H. Koechlin, Mémoires de la tour Eiffel à la chirurgie plastique (Lausanne: L'âge de I'homme, 1978), 149; Fardeau A., Les secrets de la chirurgie plastique, (Paris: Elsevier, 1975), 202. Comiskey defends a very similar idea. See Comiskey, 'Cosmetic Surgery'.

${ }^{5}$ Here we are referring to the social world as understood by Becker. Rather than adopting an a priori definition of group boundaries, this approach aims to
}

identify the fluid network of actors which develops around a still loosely defined activity. Once revealed, this network, in turn, allows us to establish how the specific world works; it permits us to better understand both the activity and the professional. See H. S. Becker, Art Worlds (Berkeley: University of California Press, 1984).

${ }^{6}$ Cosmetic surgeries, nose jobs especially, had already been performed as early as the end of the nineteenth century. Bourguet, Sébileau and Dufourmentel give a comprehensive bibliographical overview of these cosmetic surgeries. See P. Sébileau and L. Dufourmentel, Correction chirurgicale des difformités congénitales et acquises de la pyramide nasale (Paris: Librairie Arnette, 1926); J. Bourguet, La véritable chirurgie esthétique du visage (Paris: Plon, 1936). 
reconstructive to cosmetic surgery came at a cost, however, as it entailed leaving a 'legitimate' practice for a discredited one. ${ }^{7}$ In the interwar period, cosmetic surgery had been the subject of intense debate and controversy which centred around the Dujarier case. The surge in the number of scientific articles, PhD dissertations and books treating cosmetic surgery that were published during the court hearings and in the following years, reflects the growing professional and social interest in the 'scandalous' practice. The trial received a great deal of media attention and was covered by much of the French daily press (Le Figaro, Le Matin, Le Petit Journal, etc.). The discourse surrounding the court case provides ample material for investigating how a once nebulous practice came to be seen as its own field of medicine. ${ }^{8}$

Starting at the end of the twentieth century, historians of science and medicine, and researchers in the social histories of the professions have been interested in the legitimisation process of new scientific knowledge. ${ }^{9}$ These studies show how some practices and specialties became established. ${ }^{10}$ These researchers consider that rhetoric plays a crucial role; they define 'rhetoric' as arguments which are collectively constructed and which constitute an integrative element in power relations. ${ }^{11}$ But this rhetoric is often seen as a propaganda tool. If arguments or speeches are interpreted from a mostly persuasive and strategic perspective, they appear disconnected from real life. The speakers' commitment to their words can therefore be minimised and even questioned. Previously, researchers have ascribed what they believed to be unspoken intentions and motives to individual speakers. This article aims to avoid the possible pitfalls of such an approach by borrowing the framework used by pragmatic sociologists. ${ }^{12}$ This method proves better at accounting for the different ways in which doctors involved in cosmetic surgery qualify

\footnotetext{
${ }^{7}$ For the sake of clarity, the term 'cosmetic surgery' will be used to refer to medical procedures that were already distinct from reconstructive surgery. Reconstructive surgery was firmly established through the work on First World War veterans' badly injured faces. See S. Delaporte, Gueules Cassées de la Grande Guerre (Paris: Agnès Viénot Editions, 2004). The war hero status, the number of wounded soldiers and the horrifying sight of the scarring help account for its immediate acceptance and popularity. In addition to the soldiers disfigured during the war or the victims of everyday accidents, reconstructive surgery also includes clubfoot, harelip or strabismus operations, to mention just the most frequent. Cosmetic surgery mainly focuses on 'correcting' wrinkles, breast ptosis and rhinoplasty.

${ }^{8}$ The great variety of terms used to refer to the practice (aesthetic surgery, purely aesthetic surgery, plastic surgery, cosmetic or structive surgery) constitutes evidence of its blurred limits.

${ }^{9}$ I. D. Crozier, 'Social Construction in a Cold Climate: a Response to David Harley, and to Paolo Palladino's Comments on Harley', Social History of Medicine, 2000, 13, 535-46 ; T. M. Porter, L. Daston and P. Dear, 'Symposium on "The Social History of
}

Objectivity"', Social Studies of Science, 1992, 225, 595-651.

${ }^{10} \mathrm{~N}$. Oudshoorn, 'United We Stand: The Pharmaceutical Industry, Laboratory, and Clinic in the Development of Sex Hormones into Scientific Drugs, 1920-1940', Science, Technology and Human Values, 1993, 18, 5-24 ; M. Raz, 'Between the Ego and the Icepick: Psychosurgery, Psychoanalysis, and Psychiatric Discourse', Bulletin of the History of Medicine, 2008, 82, 387-420; T. Woloshyn, 'Le Pays du Soleil: The Art of Heliotherapy on the Côte d'Azur', Social History of Medicine, 2012, 26, 74-93.

${ }^{11}$ R. M. Doménech, 'Scientific Rhetoric in the Consolidation of a Therapeutic Monopoly. Medical Discourses of Spanish Radiotherapists, 1895-1936', Social History of Medicine, 1997, 10, 221-42; D. Harley, 'Rhetoric and the Social Construction of Sickness and Healing', Social History of Medicine, 1999, 12, 407-35.

${ }^{12}$ For an overview of this approach as used in history studies, see S. Cerutti, 'histoire pragmatique, ou de la rencontre entre histoire sociale et culturelle', Tracés, 2008, 15, 147-68. 
their practice; with the result that the meaning they ascribe to their own actions is taken more seriously. ${ }^{13}$

Elizabeth Haiken saw cosmetic surgery as a paradigm shift in medical studies; the present article examines how cosmetic surgery and the discourse promoting it renewed the concept of medicine, and repositioned it at the crossroads of various scientific and social fields. ${ }^{14}$ By analysing the positions adopted by surgeons who defended Dujarier and who fought for the recognition of cosmetic surgery more generally, we hope to shed light on the manner in which the world of cosmetic surgery was framed, as well as on what was at stake for the larger medical arena. This, in turn, will help to elucidate why some doctors were driven to support a denigrated practice.

This study's text corpus is largely medical. ${ }^{15}$ An in-depth analysis of twelve medical journals was conducted for the period 1928-1932 alongside a less systematic study of these same publications for the interwar period. The focus of the journals varies; some treat technical themes (La Revue de Technique Chirurgicale), others focus on professional stakes, and still others are closely tied to the unions (Le Concours Médical). They also differ in outlook, treating specific fields or general medicine, strictly medical or surgical topics, or questions related to hospital themes. The reviews analysed thus represent the diversity of the medical press that existed at that time and may, therefore, be considered a reflection of their editors' and publishers' viewpoints. This paper examines these reviews' explicit discourse regarding the trial and cosmetic surgery more generally, as well as the publications' topical oversights, that is, the subjects which appear to have been deliberately under-reported. Other documents included in this study are books devoted to cosmetic surgery and PhD dissertations on medicine defended in Paris, as the city had the highest number of doctors involved in cosmetic surgery in France. Records and archives were also examined at the Archives de Paris, the Assistance Publique-Hôpitaux de Paris and the Académie de Médecine.

The article will start by putting the Dujarier case into context in order to better understand its wider background. Then, the analysis will focus on how the medical community and individuals rallied around the case. Particular attention will be paid to distinguishing the trial from its appeal, as the controversies triggered by both clearly differ. The fourth part of this paper will examine the impact of the two trials on the practice of comestic surgery. More specifically, it will look at the change in surgeons' attitudes towards their patients and towards the transfer of medical information. Finally, we will discuss the therapeutic arguments put forward in defence of cosmetic surgery. These arguments were specifically used to rally surgeons behind Dujarier, but also played a key role in legitimising cosmetic practice throughout the interwar period.

\footnotetext{
${ }^{13} \mathrm{~J}$. Pressman, 'Sufficient promise: John F. Fulton and the origins of psychosurgery', Bulletin of the History of Medicine, 1988, 62, 1-22.

${ }^{14} \mathrm{E}$. Haiken, Venus Envy. A History of Cosmetic Surgery (Baltimore, MD: John Hopkins University press, 1997).
}

\footnotetext{
${ }^{15}$ La Vie Médicale, Revue de Technique Chirurgicale, Le Bulletin Médical, Le Concours Médical, Courrier Médical, La Gazette des Hôpitaux, La Médecine Internationale, Paris Chirurgical, Paris Médical, La Presse Médicale, Revue de Pathologie Comparée, Bulletins et Mémoires de la Société des Chirurgiens de Paris.
} 


\section{The 1929 Dujarier Trial: Cosmetic Surgery in the Dock}

The immediate post-war period opened up new horizons and fresh challenges for cosmetic surgery. There was growing interest in it as it found its way into the press. ${ }^{16}$ It was even the subject matter of a play, 'Il était une fois' (Once Upon a Time), performed at the Théâtre des Ambassadeurs. ${ }^{17}$ It is nevertheless quite difficult to quantatively assess the importance of cosmetic surgery during this epoch, as it remained loosely structured. There existed neither a recognised university degree nor specific training for the practice. It is striking that so few references can be found to cosmetic surgery in the Rosenwald guide, a directory listing all French doctors. ${ }^{18}$ For a long time, Raymond Passot was the only surgeon who qualified his practice as 'exclusive cosmetic surgery'; other practitioners describe themselves as 'ear, nose, and throat specialists' or 'cervico-facial' surgeons. ${ }^{19}$ This observation suggests three things. First, it signals that cosmetic surgery was somewhat hidden from view, due to a pervading aura of scandal surrounding the practice. The polemics addressing the use of paraffin can be cited as evidence of such reluctance. Paraffin had been in use since the end of the nineteenth century, mostly being injected to remodel noses and breasts. ${ }^{20}$ But this practice was highly condemned after the First World War due to the numerous complications it caused (localized tumours, polyarthritis, in some cases death). Many of the surgeons conducting cosmetic surgery saw themselves as misunderstood pioneers and felt they were being marginalised, even scorned. Second the Rosenwald directory shows how these practitioners positioned themselves in a fiercely competitive Parisian market. ${ }^{21}$ The demand for cosmetic operations was not yet high enough for all of them to devote their practices to that type of surgery. The double listings in the Rosenwald guide are quite revealing of the steep challenge they had to face; they needed to fill their surgical blocks while developing this new activity at a time when most clients could not afford procedures that were not covered by the national health care system. ${ }^{22}$ Third many practitioners, often hospital doctors, performed reconstructive surgery and sometimes even cosmetic surgery, under the titles of otorhinolaryngologist, stomatologist or dermatologist. While it is true that

\footnotetext{
${ }^{16}$ There were more and more references to it in women's magazines throughout the 1930s. See A. Denizot, 'Comment se débarrasser du double menton', Votre Beauté, 1936, 48, 43 and 62; A. Denizot, 'L'opération des seins', Votre beauté, 1936, 50, 389; A. Denizot, 'Rajeunissez votre visage', Votre Beauté, 1937, 61, 34-5; A. Denizot, 'Rajeunir ses yeux, c'est escamoter dix ans', Votre beauté, 1937 Noël's special number, 57-8; C. Claoué, Visage sur mesure, Marie-Claire, 1938, 84, 47.

${ }^{17} \mathrm{E}$. Bourgoin, Les possibilités de la chirurgie esthétique (Paris: Editions Lacroix Frères, 1933).

${ }^{18}$ Guide Rosenwald. Médical et pharmaceutique (Paris: Imprimerie Lang). The years 1922, 1927, 1932/33 and 1938 were consulted. As Weisz warns, this directory should be used with caution. Since the guide was solely established on doctors' self-reports, we can only extrapolate for the reality of the practice. See G. Weisz, 'Mapping Medical Specialization in Paris in the Nineteenth and Twentieth Centuries', Social History of Medicine, 1994, 7, 177-211.
}

\footnotetext{
${ }^{19}$ Raymond Passot, among others, was a resident under Morestin. Morestin was famous for his work on the 'Gueules cassées' and as Head of the Dermatology Department of the hôpital Saint-Louis had developed a strong interest in plastic surgery. Later on, Passot met Sébileau-another pioneer who trained many plastic and reconstructive surgeonsand who was also drafted to care for disfigured soldiers.

${ }^{20} \mathrm{R}$. Passot, Chirurgie esthétique pure, techniques et résultats (Paris: Doin, 1930); Bourgoin, Les possibilités de la chirurgie esthétique.

${ }^{21} \mathrm{P}$. Pinell, 'Champ médical et processus de spécialisation', Actes de la Recherche en Sciences Sociales, 2005, 156-157, 1-2, 4-36; Weisz, 'Regulating Specialties'.

${ }^{22}$ According to our low-end estimate, in the 1930 s at least a dozen surgeons were practising cosmetic surgery exclusively; all of them working in the private sector.
} 
many of these surgeons were trained as nose, ear and throat specialists or as facial surgeons, a large proportion of these doctors' scientific publications was devoted to breast surgery. It is telling that they chose to associate their practices solely with the face and head in the Rosenwald guide. Such an emphasis points to a desire to be seen as continuing the laudable work of the doctors who operated on the Gueules Cassées. Indeed, many openly claimed to belong to that esteemed group of practitioners.

Cosmetic surgery gradually came out of the shadows in the mid-1920s. More and more surgeons and clinics, such as the Landy Clinic in Saint-Ouen, began advertising their expertise in the practice. The number of practitioners registered as 'facial cosmetic' surgeons increased from eight in 1927 to 34 in 1932/33 (listed as performing 'cosmetic, maxillofacial, head and neck' surgeries'), and reached a total of 50 in 1938. A wave of advertisements for clinics specialising in the practice appeared in women's magazines. The trend was part of a wider concern for body care in France during the first half of the twentieth century. The number of beauty salons was skyrocketing and the cosmetics industry, which increasingly associated technology with body care, was soaring; food supplements to improve the skin and breasts were competing against pills and creams on the same market and against more technical devices which aimed to firm up tissue. ${ }^{23}$ Women's magazines blurred the lines between the cosmetic and medical domains. Beauty salons began employing more scientific vocabulary to sell their products and services, and advertisements for doctors involved in cosmetic surgery were often found near those for aestheticians; this situation generated market competition. The 'Youth' institute fought wrinkles using an 'intracellular method' while the Jeanne Piaubert centre proposed 'non-invasive breast correction'. ${ }^{24}$ The body was also endowed with a political dimension, and even more so after the 1870 military defeat. ${ }^{25}$ It was increasingly perceived in terms of degeneration-regeneration, and anatomy was both the result and the engine of change. Hygiene and moral recommendations were abundant. Educators, whether they were teachers, soldiers, moralists, or doctors generally associated health with body appearance through the use of medical jargon. ${ }^{26}$ Part of this general trend was a new advocacy for physical exercise, a main theme in many women's magazines; it urged individuals to take responsibility for their own bodies. Physical appearance was no longer understood as being entirely predetermined; it could be improved through exercise. Therefore, individuals could be seen as 'deserving' or 'undeserving', depending on the amount of effort they invested in maintaining their bodies. ${ }^{27}$

Having touched upon the multiple meanings attributed to one's physical appearance, the article now returns to an analysis of the trials. If medical malpractice trials were rather

\footnotetext{
${ }^{23} \mathrm{G}$. Vigarello, Histoire de la beauté. le corps et l'art d'embellir (Paris: Seuil, 2004).

${ }^{24}$ Votre Beauté, avril 1938, 278.

${ }^{25}$ Notably, this defeat resulted in the loss of a sizeable section of French territory.

${ }^{26}$ That kind of attention paid to the body by organisations promoting pro-natalist policies or naturism is quite revealing: both denounce the harmful effect of
}

modern lifestyles and advocate firming up muscles. See A. Baubérot, Histoire du naturisme. le mythe du retour à la nature (Rennes: PUR, 2004); R. Nye, Crime, Madness and Politics in Modern France: the Medical Concept of National Decline (Princeton: Princeton University Press, 1984).

${ }^{27}$ Vigarello, Histoire de la Beauté. 
uncommon in the nineteenth century, they were much less so in the interwar period. ${ }^{28}$ The fear regarding such lawsuits, as relayed in medical journals during this period, points to the increasing frequency of medical judicial decisions. ${ }^{29}$ Cosmetic surgery had already been in the dock at least twice before the Dujarier court case. ${ }^{30}$ In the Dujarier case, the plaintiff, Mademoiselle Geoffre, was a young Parisian woman; she was about to get married and had just opened a fashion house in the Concorde district after having saved for a number of years. The only cloud on the horizon of this success story was the hypertrophy of adipose cells affecting her legs. The premium put on appearance in her line of work at a time when a leaner body figure and bare legs were fashionable, may have stirred her desire to undergo cosmetic surgery. ${ }^{31}$ The young woman first consulted Charles Dujarier in February 1926. Dujarier (1870-1931) was a renowned osteoarticular surgeon, whose treatise on anatomy of limbs had become a classic. As head surgeon at the Boucicaut hospital and head of Clamart hospital's anatomical theatre, his expertise was irrefutable. He had been awarded all of the prestigious medical and university titles but one, the agrégation, a title only few practitioners could boast of having obtained. ${ }^{32}$ Born into a family of academics, his surgical aptitude was identified early on. Moreover, he was accepted into the prestigious Paris residency programme in 1905 and became Department Head in 1913. But the surgeon was not well versed in cosmetic surgery in 1926, so it seems odd that, in spite of the singularity of Mademoiselle Geoffre's case, he agreed to perform the operation. ${ }^{33}$ Stranger still, Dujarier agreed to perform the operation free of charge in his department of the Beaujon hospital, and not in his clinic, presumably because of the exploratory nature of the procedure and its scientific interest. His decision proved controversial as debates were already raging over whether hospitals should extend their care to non-indigent patients. ${ }^{34}$ The young woman was admitted to the hospital the day after her first consultation with Dujarier, and the operation took place the following day. She was told the surgery would

${ }^{28} \mathrm{~A}$. Dracobly, 'Ethics and experimentation on human subjects in mid-nineteenth-century France: The story of the 1859 syphilis experiments', Bulletin of the History of Medicine, 2003, 77, 332-6; G. Weisz, 'Regulating Specialties in France during the First Half of the Twentieth Century', Social History of Medicine, 2002, 15, 457-80.

${ }^{29} \mathrm{P}$. Barlerin, 'Correspondance: à propos des scandales médicaux', La gazette des hôpitaux civils et militaires, 20 février 1929, 15, 270; B. Orticoni, 'A propos d'un procès à Auxerre', Le Concours Médical, 1928, 50, 822-3.

${ }^{30}$ Two cosmetic surgeons had been tried in 1913, one lost on appeal in 1920. In both cases, the court found the practitioner and the practice reprehensible and twice concluded that the treatment was disproportionate to the aim. See La Gazette du Palais, 1921, 1, 68; L. Kornprobst, 'Les responsabilités encourues devant les tribunaux en matière de chirurgie esthétique et réparatrice', Annales de Chirurgie Plastique, 1970, 15, 236-44.

${ }^{31}$ Vigarello, Histoire de la beauté.

${ }^{32}$ Records of the I'AP-HP, 672FOSS3; 773FOSS6; P. Mathieu, 'Nécrologie, Charles Dujarier', La semaine des hôpitaux de Paris, décembre 1931, 595-7.
${ }^{33}$ The medical community considered that doctors were multipurpose and that the title of doctor entitled them to perform all types of operations. This is why practitioners came to see medical specialisation as infringing on their power, and by extension on their clientele (see Weisz, 'Regulating Specialities'). As for surgery, many procedures were of an experimental nature. See S. Wilde, 'Truth, Trust, and Confidence in Surgery, 1890-1910: Patient Autonomy, Communication, and Consent', Bulletin of the History of Medicine, 2009, 83, 302-30. It is well accounted for by the pioneers of cosmetic surgery, see Passot, Sculpteurs de visages; M. Virenque, Le sein (Paris: Editions Médicales Maloine, 1929).

${ }^{34}$ The role of hospitals was hotly debated in the 1920 s. Hospitals were originally designed to provide free health care only to the destitute, but in the interwar period they extended their care to paying patients. Private doctors feared this new unfair competition would affect their business. This debate was part of wider concerns over health care provision in France at the time. See P. Guillaume, Le Rôle Social du Médecin depuis Deux Siècles, 1800-1945 (Paris: Comité d'Histoire de la Sécurité Sociale, 1996). 
be neither lengthy nor particularly risky. But the procedure proved more complex and the removed fatty substance larger than expected. ${ }^{35}$ The surgeon had difficulty suturing and elected not to operate on the second leg. The patient's state quickly deteriorated. Within a few days, gangrene set in and the surgeon was forced to amputate. Dujarier would later be criticised for the overly eager yet casual manner in which he approached the operation. The surgeon's terseness when dealing with his patients, especially with this young woman who was about to marry, only made matters worse. ${ }^{36}$

The case was first examined by the civil court of the Seine in February 1929. At that time, Mademoiselle Geoffre, who had since become Madame Le Guen, was unemployed, as the long post-operation care had forced her to close her fashion house. Maître Théry, Madame Guen's lawyer, denounced Dujarier's relaxed attitude and argued that the doctor had played down the risks of the operation. But it was on the surgeon's mandate and on the legitimacy of cosmetic surgery itself that Maitre Flach, the deputy prosecutor, chose to focus. The delineation of the doctor's mandate was inextricably tied to the ends pursued; were they exclusively cosmetic or did they have some therapeutic merit? The medical act was defined more by the practitioner's objectives then by the specific techniques employed to carry out the act. According to Maître Thorp, the defence lawyer, cosmetic surgeries were a legitimate means of fighting against taunting, and even suicide. Maître Théry, however, considered them frivolous and argued that they exemplified 'a woman or a man's vanity, their desire to follow a trend'. ${ }^{37}$ His plea was a risky balancing act: he needed to demonstrate the vanity of his client's request and at the same time show that she acted sensibly in her careful choice of a renowned, respected surgeon. He had to establish her shallowness but avoid painting Madame Guen as insouciant. Théry played up the social, psychological and gender imbalance between the surgeon and his client to highlight the recklessness of the surgeon's behaviour. Mademoiselle Geoffre was portrayed as a 'little seamstress without any medical knowledge' who was facing 'the great man of science'. The surgeon's moral authority should have encouraged him to adopt a paternalistic attitude the lawyer affirmed: Dujarier should have 'scolded her. ... You're not being serious! You can't risk your life or jeopardize your physical integrity out of pure vanity'. ${ }^{38}$ As the surgeon had the moral authority to decide which procedures were 'just' and ethical, he was duty-bound to set limits on what would be done. The court partly sided with this view when it condemned Dujarier to pay Fr 200,000 in damages. ${ }^{39}$ Downplaying the aesthetic problem, 'a minor physical imperfection which was, moreover, relative', the judge inferred that it was in no way pathological and denied the surgery any therapeutic merit. Thus, the practice of cosmetic surgery itself, defined exclusively by its aesthetic aims (to operate on a 'healthy member with the sole purpose of correcting the silhouette'), was called into question.

\footnotetext{
${ }^{35}$ Glicenstein, 'L'affaire Dujarier'.

${ }^{36} \mathrm{E}$. Saint-Auban, 'La chirurgie esthétique'. For Dujarier's characteristic bluntness toward his patients, see Charles Dujarier 1870-1931 (Paris: Imprimerie Lahure).
}

\author{
${ }^{37}$ Ibid., 201. \\ 38/bid., 202. \\ ${ }^{39} € 110,000$ today.
}




\section{A Profession Rallying behind a Cause and an Individual}

The debate over the legitimacy of cosmetic surgery that was initiated in the courtroom quickly moved to the medical arena. This trial, and its appeal several years later, aroused intense emotions in both the daily and especially the professional press, to such an extent that it caused a deep rift within the medical community.

In this section we will examine the factors that scandalised these professionals and what made them shift from their initial condemnation of Dujarier, whose medical act was illegitimate in the eyes of many, to rallying behind a common cause at a time when doctors feared both a growing number of medical practitioners and State interference in their practice. ${ }^{40}$ First we will consider who rallied and took action. Then we will study the motives behind this mobilisation.

Both trials triggered a surge in the number of articles on cosmetic surgery published in medical journals. These journals were being used to raise awareness of the Dujarier trials by relaying information about the proceedings, but also by serving as opinion forums. The majority of the concerned contributors supported Dujarier and defended the practice of cosmetic surgery. Dujarier's champions utilised the journals to convince and rally readers. They also pushed for backing him more directly by mobilising their own circles of acquaintances; personal and professional contacts and social interaction played a crucial role in raising support for their cause. ${ }^{41}$

The first supporters were the surgeons whose medical practices were affected by the court's decision. Foremost among them was Louis Dartigues, chief organiser of Dujarier's support network. Dartigues acted as a magnet thanks to his extraordinary interpersonal skills and stamina. ${ }^{42}$ He managed to gather a few faithful followers, including Charles Claoué and Julien Bourguet, ${ }^{43}$ whom he later convinced to establish a scientific society. At the same time, a journal exclusively dedicated to plastic and cosmetic surgery emerged, Revue Française de Chirurgie Réparatrice Plastique et Esthétique. Personal rivalries, however, hindered Dujarier's advocates from presenting a united front. For Raymond Passot and Léon Dufourmentel, Dartigues lost all credibility when, in

\footnotetext{
${ }^{40}$ They feared that there were far too many doctors in France: the number of doctors had increased by $70 \%$ between 1876 and 1931; see Weisz, 'Regulating Specialties'. In addition, throughout the 1920s, health care reform was the subject of intense debate in the medical community. Unions denounced the growing interference of the state and the infringement of their practice. See M. Brémond, 'Les Syndicats de Médecins Contre l'Organisation de la Protection Sociale, Tout Contre', Pouvoirs, 1999, 89, 119-34; Pinell, 'Champ Médical'.

${ }^{41}$ Crozier, 'Social construction'; Pressman, 'Sufficient promise'.

${ }^{42}$ Louis Dartigues (1869-1940) presided over the Société des Chirurgiens de Paris and the Société de Médecine de Paris. He was also a member of many organisations and unions. He had additionally been
}

granted official honours (légion d'honneur) and medical recognition, having been awarded many prizes. He was also a prolific author. See L. Dartigues, Faisceau scriptural (Paris: Doin, 1932); G. Baillière, 'Louis Dartigues', Paris médical: la semaine du clinicien, 1940, 116/118, 319-20.

${ }^{43}$ Claoué had a provincial, bourgois medical background; his father was an important otorhinolaryngologist in Bordeaux. Educated in the south-west, Claoue then travelled to Paris where he became a very successful cosmetic surgeon at the end of the 1930s. Bourguet (1877-1952), who had also studied in Provence, arrived in Paris before Claoué, and began practising facial cosmetic surgery shortly before the start of the 1920s. Perhaps due to his earlier arrival, Bourguet enjoyed even higher visibility throughout Paris than his famous peer. 
collaboration with Serge Voronoff, he began promoting the graft of monkeys' testes on men. ${ }^{44}$ Moreover, Dufourmentel and Bourguet's distain for one another was evident in their recurrent fiery confrontations. The atmosphere was replete with tension and animosity, against a backdrop of steep competition. Additionally, most of Dujarier's advocates had private practices; this fact, combined with the negative image that cosmetic surgery held at the time, deterred the most famous reconstructive surgeons, such as Victor Veau, Fernand Lemaître and Louis Ombredanne, from actively supporting Dujarier. ${ }^{45}$ Another obstacle to a unified mobilisation effort was that, after the First World War, reconstructive surgeons were scattered throughout numerous hospitals and reconstructive surgery merged with a wide variety of other specialities.

Beyond this initial circle of supporters, other doctors began rallying more in defence of the autonomy of medical professionals than in defence of Dujarier himself. For these doctors, the case was not about the professionalism of a specific surgeon; rather, it was a concrete example of how the practice of medicine could fall victim to the judicial machinery, which could impugn both the exercise of the profession and its underlying moral principles. Dujarier's professional status encouraged doctors to join in the defence of a medical practice that the unions broadly painted as being at risk. ${ }^{46}$ The realisation that any member of the medical profession, even one of the elite, could be attacked only heightened collective fears. The doctor's position as a leading medical professional helped foster mobilisation, as did the fact that he held neither the title of professor nor that of 'agrégé'; in short, he was able to capitalise on his reputation as an eminent surgeon without being seen as a moraliser. ${ }^{47}$ Two major signs that the medical community were backing Dujarier were the involvement of the Syndicat des Chirurgiens des Hôpitaux et Hospices Civils de l'Assistance during his appeal and the letter of support from the Secretary General of the Association Générale des Médecins de France (AGMF) that was sent to all scientific societies. ${ }^{48}$

Yet support within the medical community for Dujarier's cause was far from unanimous. The aforementioned evidence of backing for Dujarier should not lead the observer to presume that he enjoyed the approval of every member of his profession. Medical journals tended to reflect the stance of their editorial boards; those boards were generally composed of members of the elitist Parisian vanguard, bound to feel fellowship with a surgeon from a Parisian public hospital. Moreover, doctors involved in cosmetic surgery excepted, his main supporters often had vested interests in getting involved: the unions to demonstrate their ability to defend and other medical professionals in order to

\footnotetext{
${ }^{44}$ Passot, Sculpteur de visage; L. Dufourmentel, Introduction à la chirurgie constructive, essai sur l'art et la chirurgie (Paris: La Jeune Parque, 1946), 194-6. Léon Dufourmentel (1884-1957) succeeded Morestin in 1919 and became department head at the Foch hospital in 1936. He was a member of the Académie de Chirurgie. He was also Sébileau's sonin-law and trained under him.

${ }^{45}$ Among the hospital practitioners, only Pierre Sébileau, Léon Dufourmentel and Jean-Louis Faure wrote a small number of articles that they signed in their own name and not on behalf of the group. Besides, when Dartigues offered the honorary chair-
}

manship of the scientific society to hospital surgeons, they would turn it down. L. Dartigues, 'Séance du 29 janvier 1932', Revue française de chirurgie réparatrice plastique et esthétique, 1932, 1, 25-7.

${ }^{46}$ Brémond, 'Syndicats de médecins'; Weisz, 'Regulating specialities'.

${ }^{47}$ As mentioned in Weisz ('Regulating specialities') and Brémond ('Syndicats de Médecins'), tensions were rife between the medical elite and the grassroots, as they considered that the elite imposed its directives.

${ }^{48}$ Lettre de soutien du secrétaire général de I'Association Générale des Médecins de France, La Vie Médicale, 25 juillet 1929, 733-4. 
improve their business. Gabriel Duchesne is a case in point: as Secretary General of the Sou Médical (a medical professional liability insurance company), he used the trial on several occasions to encourage doctors to purchase insurance through his organisation. ${ }^{49}$ Conversely, the few dissenting voices condemning Dujarier's behaviour were mostly unknown provincial doctors who in all likelihood represented a silent majority that was reluctant to accept the practice of cosmetic surgery and endorsed views expressed in professional injunctions favouring self-regulation. ${ }^{50}$ Solidarity mechanisms have full hold: in the medical community, a professional mistake was rarely publicly denounced; at best, it was criticised in private, escaping the eyes of medical journal subscribers as well as those of the greater public. ${ }^{51}$ Opposition to Dujarier must be analysed through what is left unsaid and from evasions. The paucity of responses to the AGMF's letter of support, for example, reveals a certain general discomfiture vis-à-vis the issue. The Société Nationale de Chirurgie de Paris as well as the Société de Médecine de Paris hid behind an ostensibly scientific non-involvement in order to avoid taking official positions. As for the Académie de Médecine, it never even replied to the letter. ${ }^{52}$ Even more revealing, certain doctors involved in cosmetic surgery, such as Raymond Passot and Suzanne Noël, neglected to heed the rallying cry and at times openly questioned Dujarier's carelessness.

Two main elements must be taken into account to better understand the motives behind this mobilisation. First, the growing importance given to legal matters in medical journals in the 1920s raised doctors' awareness of legal issues and fostered their distrust of the judicial institution. ${ }^{53}$ Insurers fuelled this apprehension in their own interests. Simultaneously, at the turn of the twentieth century, doctors' unionisation rate increased sharply; they were therefore more likely to defend common causes. The Confédération des Syndicats Médicaux Français unified 80 per cent of all practitioners in 1927, compared to 60 per cent in $1921 .^{54}$ These two factors together created fertile ground for a fight for the common cause, that is, the defence of a purportedly endangered medical practice under legal attack.

In the months following the first trial, the activists put forth general arguments in an effort to rally the largest number of possible participants. The campaign also adopted a more specifically 'cosmetic surgery' perspective, which continued to be its approach throughout the interwar period and will be analysed in the following section of this paper. The first set of arguments contended that the trial represented an infringement of medical autonomy; this claim had the potential to move the entire medical community to action. The prosecution of Dujarier is presented as an indictment of medicine as a whole. Dujarier's supporters interpreted the court ruling as a broader sign of how difficult it had become to practise medicine. They used broader arguments, rather than just focusing on the defence of cosmetic surgery, in an effort to convince the entire medical community

\footnotetext{
${ }^{49} \mathrm{G}$. Duchesne, 'Sou médical: la défense individuelle du médecin. Si vous craignez les procès, venez au sou médical', Le Concours Médical, 19 février 1930, $52,7,525-7$.

${ }^{50} \mathrm{Dr}$ Jean is such a doctor who describes himself as a 'country doctor'. See Jean, 'Variations sur l'Ordre des médecins et sur une jambe coupée', La Vie Médicale, 25 avril 1929, 410; A. Constant, 'De la responsabilité du chirurgien', L'Hygiène Sociale, 25 mars 1929, 11.
}

\footnotetext{
${ }^{51} \mathrm{E}$. Freidson, Profession of Medicine. A Study of the Sociology of Applied Knowledge (New-York: Harper and Row, 1970).

${ }^{52}$ Archives of the Académie de Médecine.

${ }^{53}$ Among others, see Barlerin, 'Correspondance'. See also Dracobly, 'Ethics and Experimentation' and Weisz, 'Regulating Specialties' in particular on coverage in the 1920s.

${ }^{54}$ Brémond, 'Syndicats de Médecins'.
} 
to join their fight. By leaving the discredited practice of cosmetic surgery out of the debate, they left little room for criticism and opposition. The court ruling was deemed unjust by the surgeon's advocates and described as evidence that the sword of Damocles was hanging over the head of every medical professional, as, according to his supporters, Dujarier had been charged simply for 'having performed the operation'. ${ }^{55}$ As Duchesne put it, [Every doctor] will have to accept that he may be sued at any time, even when he least expects it. ${ }^{56}$

This assessment was seconded by legal professionals whose opinions were published in medical journals and served to augment the general anxiety. ${ }^{57}$ Dujarier's trial was no longer presented as a case of an elite surgeon having performed a cosmetic procedure, but as a legal battle that attested to the vulnerability of the entire medical community. In this way, an individual trial was transformed into a common ordeal.

The mobilisation is framed as a fight for medical autonomy in the face of external regulation. While denouncing medical ignorance and the meddling of the judicial system, these health professionals insisted on the adverse impacts that additional legal constraints would have on quality of care, technological innovation and research. ${ }^{58}$ Resorting to nineteenth-century rhetorical arguments, these doctors enlisted the virtues of science and the values of the Enlightenment, presented as neutral and universal. ${ }^{59}$ The mobilisation efforts even took on the appearance of a crusade 'against the unjustified attacks of the laymen, the ill-informed, the ignorant, whose backward ideas are hostile to innovation' and in support of 'surgeons who, like pioneers, embark on adventures which hazard their honor, reputations, fortunes, indeed, their very freedom' ${ }^{60}$ These surgeons claimed the moral high ground which allowed them to reaffirm their own grandeur, even as they maintained that they were fighting for the common good. Such praise of science was still relatively immune to scandal and regulation at that time, lending a certain weight to the debate. Failure is accepted as a medical eventuality and the adversities of its victims are viewed as unfortunate but tolerable collateral damages, sacrifices at the altar of Progress. Some arguments smell of fatalism while others contend that the illfated operation was statistically insignificant: 'if he had to sacrifice one leg to avoid disastrous complications, [he] healed and saved thousands of legs'. ${ }^{61}$ Where the 'contingency'

${ }^{55} \mathrm{G}$. Duchesne, 'La responsabilité en chirurgie', Le Concours Médical, 17 mars 1929, 51, 11, 910.

${ }^{56} \mathrm{G}$. Duchesne, 'Pluie de condamnation', Le Concours Médical, 13 mars 1929, 51, 10 bis, 805.

${ }^{57} \mathrm{P}$. Boudin, 'Jurisprudence: responsabilité des médecins, chirurgie esthétique, prétendue nécessité morale (non)-responsabilité de droit commun', Le Concours Médical, 14 avril 1929, 51, 1206; H. Ribadeau Dumas, 'Jurisprudence et législation: responsabilité médicale, chirurgie esthétique', La Gazette des Hôpitaux, 22 juin 1929, 50, 923-6.

$58 \mathrm{~J}$. L. Faure, 'Chroniques variétés et informations: la chirurgie esthétique et les magistrats', La Presse Médicale, 28 octobre 1933, 86, 1676-8; B. Orticoni, 'A propos d'un procès à Auxerre', Le Concours Médical, 1928, 50, 822-3.
${ }^{59}$ D. Gavrus, 'Men of dream and men of action: neurologists, neurosurgeons, and the performance of professional Identity, 1920-50', Bulletin of the History of Medicine, 2011, 85, 57-92; Saint-Martin A., 'Autorité et grandeur savantes à travers les Eloges Funèbres de l'Académie des Sciences à la Belle Epoque', Genèses, 2012, 87, 47-68.

${ }^{60}$ Dartigues quoted by $\mathrm{S}$. Gardès, L'esthétique et le droit. Responsabilité du chirurgien (Toulouse: Edouard Privat, 1932), 8-9.

${ }^{61}$ L. Dartigues, 'Le droit à la chirurgie esthétique, rapport présenté au conseil général de l'Association Générale des Médecins de France', La Vie Médicale, 25 mars 1929, 10, 289-97, 290. 
frame prevailed in medical circles, the surgeon was cleared of all responsibility; he simply represented the armed wing of Science, which was largely understood as a legitimate custodian of truth.

Even though no official medical board of ethics existed in France at the time, these doctors did not disregard moral concerns, but they favoured general principles over codes of conduct. ${ }^{62}$ Although most admitted that some regulation was necessary, they demanded that it be limited in scope and touted self-regulation. Blurring the lines between the medical code of ethics and a supposed set of universal values made such demands possible. This type of governance would refuse legal prerogative and external regulation, which were considered excessively bureaucratic and detrimental to the common good. The idea was that the fear of a lawsuit would hinder practitioners' foolhardiness. For Foveau de Courmelles, Dujarier's trial cast a dark shadow over the future of medical progress:

Whenever judicial courts take it upon themselves to judge medicine, they degrade it; they reduce its scope and its potential to save lives. It will spell the death of so many patients which doctors could have saved or tried to save. Instead they will limit themselves to standard procedures. Medical progress will no longer be possible! ${ }^{63}$

Medical progress was systematically associated with risk-taking. Three characteristics of the surgeon culture during the interwar period were a desire for innovation, faith in trailblazers and a willingness to venture into experimentation. ${ }^{64}$ This interwar culture was made plain when Dujarier's supporters began extolling the legacies of Pasteur and Jenner (who conducted risky experiments in order to invent vaccines against rabies and smallpox, respectively). ${ }^{65}$

\section{Informing the Patient: An Evolution in Doctor-Patient Relations?}

The appeal hearing in 1931 impacted both mobilisation and the arguments made in defence of Dujarier. Even the lawyers' lines of reasoning evolved throughout the trial. Instead of directly condemning cosmetic surgery, Théry, the plaintiff's lawyer, developed a paradoxical conception of patient information. He asserted that surgeons had an obligation to explain fully to the patient the procedures and the available options, but that it was also a doctor's duty to refuse to operate if moral or health imperatives required it. While the court ruling lifted the ban on cosmetic surgery, it also insisted on Dujarier's moral responsibility, finding him guilty of not having properly informed the patient.

The surgeon failed to sufficiently inform his patient of the grave risks involved in the operation; the patient must be fully apprised of the dangers of the operation and give his informed consent to it. These are absolute obligations when the aim of

${ }^{62} \mathrm{R}$. Nye, 'Médecins, ethique médicale et etat en france 1789-1944', le mouvement social, 2006 , 214, 19-36.

${ }^{63}$ Foveau de Courmelles, Le Courrier Médical, 14 avril 1929.
${ }^{64} \mathrm{~S}$. Wilde and G. Hirst, 'Learning from mistakes; early twentieth century surgical practice', Journal of the History of Medicine and the Allied Sciences, 2008, 64, 38-77.

${ }^{65}$ Dartigues, 'Droit à la chirurgie esthétique'. 
the operation is not to cure a patient from an illness but merely to reduce or remove a physical imperfection. ${ }^{66}$

This ruling reinforced the distinctive nature of cosmetic surgery; according to this decision, the practitioner's responsibility depended on the curative or cosmetic nature of the surgery. While in most surgical procedures patient information could be limited, in cosmetic cases the duty to inform was reinforced, and therefore clashed with the paternalistic ethos prevalent in the medical world. Consequently, the fully informed patient could have more influence in the decision making process. ${ }^{67}$

Even as the court ruled against him for a second time, support for Dujarier was faltering. The trial was overshadowed by the many other professional issues that were being discussed at the end of the 1920s: the social insurance system, the remuneration of medical acts (the law was passed in 1930), the redefinition of the role of public hospitals, and the creation of a French Medical Association all took pride of place. ${ }^{68}$ Moreover, as the appellate decision did not target cosmetic surgery per se but mainly focused on an individual case of malpractice, it could not easily serve as a goad to mobilisation. Many medical journals still covered the trial; however, most articles were devoted to the practice and merits of cosmetic surgery with special emphasis on how to manage patient information and consent, which had become the crucial issues following the appeal. ${ }^{69}$

Two separate points of view emerged vis-à-vis patient information; they were based on diverging opinions regarding the therapeutic benefits of cosmetic enhancement. How one defined appropriate patient-surgeon relationships depended largely on how one understood the added value of a particular procedure. For those who considered that cosmetic surgery was salutary, there was no need to fully inform the patient; this type of operation was not fundamentally different from classic surgical procedures. For others, cosmetic surgery was beneficial but not indispensible; as the risks outweighed the benefits, they believed that the patient had to be perfectly conscious of the dangers involved. The first medical professionals considered that cosmetic surgery was no different to any other medical specialty and advocated using patient information strategically, in what they described as the best interests of a patient who may not be capable of identifying those interests himself. ${ }^{70}$ Unable to understand the objective risks of the operation, the patient could be misled by his ignorance and emotions. Information should then be diluted to ease the patient's worries, or conversely enhanced to increase his anxiety and justify the surgeon's refusal to operate: '[the surgeon] will only allude to risk of death or mention unforeseeable complications when advising against a procedure or when refus-

${ }^{66}$ E. Saint-Auban, 'La chirurgie esthétique en appel', Revue des grands procès contemporains. Recueil d'éloquence judiciaire, 1931, 345-404, 403.

${ }^{67}$ Wilde and Hirst, 'Learning from mistakes'.

${ }^{68}$ Guillaume, rôle social.

${ }^{69}$ If the Dujarier trial gave a boost to the number of articles dealing with cosmetic surgery, their number kept increasing from the mid-1920s and throughout the 1930 s even if they were less and less related to the case.

${ }^{70} \mathrm{~L}$. Dartigues, 'Compte-rendu du 2ème congrès de la société scientifique française de chirurgie réparatrice, plastique et esthétique tenu à Paris les 2/3 octobre 1931', Revue française de chirurgie réparatrice plastique et esthétique, 1932, 1, 1-7; Faure, 'Chroniques variétés'. 
ing to operate' ${ }^{71}$ The information given to the patient would be adjusted in order to support the surgeon's decision and to convince the patient.

On the other hand, surgeons who advocated comprehensive patient information emphasised the specificities of cosmetic procedures, stressed the non-essential nature of the practice and minimised its therapeutic interest. ${ }^{72}$ The surgeon was seen as an advisor who 'must let the appropriately informed patient have the final say'. ${ }^{73}$ Liberal-minded practitioners asserted that the patient had a right to body transformation, and that he should be the sole judge of the risks involved. 'The client is master of his own body and should be able to receive the treatment he or she wishes' Boudin affirmed. ${ }^{74}$ This stance was unprecedented and clearly directly linked to the trial. The evolution of Passot's statements over the course of just a few years is quite enlightening in that respect. While in 1925 he upheld his right to override a patient's request when she demanded that her breasts be positioned too high, Passot appeared less dogmatic a few years later when he stressed that individual desires had to be taken into account. ${ }^{75}$ He even encouraged explaining all the different possible procedures in order to let the patient have the final say. Where multiple procedures were available, he even encouraged presenting each one in detail and leaving the choice up to the patient.

Contrary to what is generally done in standard surgical cases, for cosmetic procedures surgeons [must] go into detail, sometimes providing explanations all throughout the process and showing photographs of previous results. ${ }^{76}$

The mobilisation and debate inspired by these trials brought judicial risk to the fore and established a new category of patient: the problem patient. Articles on cosmetic surgery first mentioned this new issue in 1929 and continued to do so until the war. In this context, where the reliability and trustworthiness of the patient had to be assessed, medical journals began urging practitioners to be cautious. ${ }^{77}$ The way the main protagonists, Dujarier and Geoffre, were described only exacerbated the feelings of injustice and fear. The apologetic depictions of the condemned surgeon stood in sharp contrast to characterisations of the plaintiff as a bad patient. While he was presented as a good man, devoted to his work and to the sick, Geoffre was also painted as the embodiment of greed. The presumed ungratefulness of the patient served to build up the surgeon's philanthropic image.

${ }^{71}$ A. R. Reinoso, Considérations générales sur la chirurgie esthétique (Paris: Les presses modernes, 1934), 57.

${ }^{72}$ Practitioners' stances may here appear quite rigid while surgeons might have proved more compliant in reality and the range of practices should be considered in terms of a continuum.

${ }^{73} \mathrm{C}$. Pleindoux, 'Chirurgie esthétique et responsabilité médicale', Unpublished medical PhD, Lyon, 1932.

${ }^{74} \mathrm{P}$. Boudin, quoted by Dartigues, 'Droit à la chirurgie esthétique', 281-2.
${ }^{75} \mathrm{R}$. Passot, 'La correction esthétique du prolapsus mammaire par le procédé de transposition du mamelon', La presse médicale, 11 avril 1925, 317-18.

${ }^{76}$ Passot, Sculpteurs de visages.

${ }^{77}$ Braine, 'Discours du Docteur Braine, chirurgien des hôpitaux, secrétaire du comité', in Charles Dujarier, Discours à l'occasion de l'inauguration du médaillon Dujarier à l'hôpital Boucicaut, Charles Dujarier 18701931 (Paris: Imprimerie Lahure, 1932), 17-19; Pleindoux, Chirurgie esthétique; Sébileau, 'Chirurgie Cosmétique'; 'Courmelles Foveau (de), Intérêts professionnels: considération sur les procès médicaux', La gazette des hôpitaux 47, 7 juin 1930, 850-1. 
After he had vehemently refused the operation, Mr. Dujarier finally bent to the patient's persistent requests and agreed to the surgery on the condition that he would operate free of charge. But apparently no one had taught the patient not to look a gift horse in the mouth. Forgetful of her surgeon's disinterested and extraordinarily kind gesture, she did not hesitate to sue for damages once the operation proved a failure. ${ }^{78}$

In this way the victim was transformed into the executioner; accordingly, Dujarier's death, which occurred just a few months after the appellate decision, was seen by some as a direct result of this public disapproval. ${ }^{79}$ The patient's psyche suddenly became a crucial factor in the surgeon's decision to operate. Psychological concerns did not necessarily rule out surgery; indeed, such issues could themselves justify surgical intervention. On the other hand, surgeons were strongly advised to categorically refuse to operate should the patient be suspected of insanity.

Some patients ... believe they suffer from deformities that they don't have, or exaggerate small ones that they do have. Having undergone an initial operation, they ask for another and then another, never satisfied. ... The surgeon must distance himself from these half-insane clients. ${ }^{80}$

The practitioner was forced to move beyond the technical dimension of the consultation and seriously consider the patient's discourse, not to better respond to the patient's needs but to more easily identify potentially problematic cases. Although they were not adopted by every surgeon, new ways of dealing with patients emerged. The advent of consent forms, and the new habit of inviting patients to take pre-op photographs and to purchase pre-op insurance, constituted proof of this movement toward greater risk management. ${ }^{81}$ The optimism that had reigned in the 1920s, as evidenced in Noël's book on cosmetic surgery, gave way to precaution. ${ }^{82}$

\section{Therapeutic Arguments for Cosmetic Surgery in the Interwar Years}

In the face of general contempt for their profession, doctors involved in cosmetic surgery spent much of the interwar period affirming the therapeutic value of their practice. Medical legitimacy was based on the potential health benefits of the practice. ${ }^{83}$ It should be noted that the discourse defending the therapeutic advantages of cosmetic surgery originally emerged between the end of the First World War and Dujarier's first trial; however, it became more visible when it was employed in the surgeon's defence. This discourse, composed of three main arguments, was used in Dujarier's defence but also more broadly in defence of cosmetic surgery throughout the interwar period. ${ }^{84}$

${ }^{78} \mathrm{P}$. Bourdel, 'Discours de', in Charles Dujarier 18701931 (Paris: Imprimerie Lahure, 1932), 11.

${ }^{79} \mathrm{lbid}$.

${ }^{80}$ Sébileau, 'Chirurgie cosmétique'.

${ }^{81}$ Claoué, Chirurgie réparatrice; A. Sanchez-Puyana, 'De la chirurgie plastique mammaire. De ses indications de ses contre-indications', 1934, Unpublished medical PhD, Paris; Pleindoux, Chirurgie esthétique; Reinoso, Considérations générales; Dartigues, 'Droit à la Chirurgie Esthétique'.
${ }^{82}$ S. Noël, La chirurgie esthétique, son rôle social (Paris: Masson \& Cie, 1926).

${ }^{83}$ Doménech, 'Scientific Rhetoric'; D. Gavrus, 'Men of Dream'; Woloshyn, 'The Art of Heliotherapy'; J. R. Wright, 'The 1917 New York Biopsy Controversy: A Question of Surgical Incision and the Promotion of Metastases', Bulletin of the History of Medicine, 1988, 62, 546-62.

${ }^{84}$ We draw freely from Barbot and Cailbault who identified two main arguments used to justify resorting to cosmetic surgery in the second half of the 
The first line of reasoning treated involved the disempowerment of the body. As early as the 1920s, in order to demonstrate the value of their practice, doctors performing cosmetic surgery presented themselves as warriors against the social exclusion of their patients due to physical imperfections. Social norms, sanctifying the importance of physical appearance, tended to ostracise unattractive or deformed individuals and exclude them from daily social interactions. Contrary to classic surgery, the aim of which was to resolve health issues, social integration through the elimination of aesthetic flaws was the professed objective of cosmetic surgery. ${ }^{85}$ Physical imperfections were viewed as a hindrance to the patient's prospects who must therefore be delivered from such an injustice.

They demand [of cosmetic surgery] the right to look like anybody else, the right to be loved, the right to start a family. ... They are fighting for a better life in a society where physical considerations take pride of place. ${ }^{86}$

These professionals portrayed themselves as following in the footsteps of reconstructive surgeons, whose goal was to allow patients to conform to social norms rather than standards of beauty; these practitioners played on the poignant collective memories of maimed First World War veterans. ${ }^{87}$ Physical appearance was depicted as social capital, worth serious investment. The recognised signs that a cosmetic operation had been successful were to be found in the changes that subsequently occurred in the patient's life (getting married or finding employment), not in any observable improvement of the patient's physical appearance.

The unfortunate woman could no longer earn a living because she looked too old. She appeared so much younger after the first operation that she quickly found gainful employment ... Cosmetic surgery ... gives men as well as women the previously unimaginable opportunity to work over a longer time span. ${ }^{88}$

Such praise mirrors the socially constructed representations of the time and the importance given to physical appearance. ${ }^{89}$ This discourse is anchored in a general empathy toward and a certain popular affinity for the patient. It borrows from the lexical fields of 'abandon' and 'solitude' when describing the preoperative condition of the patient and reports a clean break from that initial state once the operation is completed. This vision was corroborated by patients who provided detailed descriptions of their tribulations in letters published in books written by doctors involved in cosmetic surgery. ${ }^{90}$ These firstperson narratives are considered self-sufficient proof of the merits of cosmetic surgery. ${ }^{91}$

nineteenth century: getting rid of the physical embarrassment is a way to 'normalize' individuals' physical appearance so as to facilitate their social integration into everyday social interactions; and facilitate these individuals' 'self-fulfilment' by helping them be themselves and be true to themselves. J. Barbot and I. Cailbault, 'Figures des Victimes et Réparation des Violences Faites aux Corps. Quand la Chirurgie Esthétique se Donne à Voir', Politix, 2010, 23, 90, 91-113.

${ }^{85}$ Sébileau, 'Chirurgie cosmétique'; Pleindoux, Chirurgie Esthétique.

${ }^{86}$ Dartigues, 'Droit à la chirurgie esthétique', 293.
${ }^{87}$ Bourgoin, Les possibilités de la chirurgie esthétique, 3; P. Mornard P., 'La résection esthétique du ventre en tablier avec transplantation de I'ombilic', La pratique chirurgicale illustrée, 1929, 15, 138-9; E. H. Perreau, 'Intérêts professionnels: caractère licite de la chirurgie esthétique', Paris Médical: la semaine du clinicien, 1937, 106, 188-91.

${ }^{88}$ Noël, La chirurgie esthétique, 7 . This surgeon in particular insists on the impact of cosmetic surgery on the job market. See Martin, Suzanne Noël.

${ }^{89}$ Haiken, Venus Envy.

${ }^{90}$ Bourguet, Véritable chirurgie esthétique, $29-30$ and $37-8$. 
As a primary beneficiary of the practice, the patient is invested with the authority to declare the value of cosmetic surgery, which is measured here by transformations in his or her everyday life rather than by its conformity to standardised medical procedure. ${ }^{92}$

This physical discrimination was exacerbated in professions in which appearance played a crucial role. Waitresses, actresses and dancers were greatly affected. According to Sanchez-Puyana, the patient's occupation could constitute a critical factor in the surgeon's decision to operate, especially in cases of minor imperfections or when the procedure could prove to be problematic. ${ }^{93}$ Bourgoin thus identified two categories of potential patients: 'those who earn a living thanks to their looks [and] those whose ugliness deprives of them of the normal life they deserve'. ${ }^{94}$ When signs of ageing became an obstacle to finding employment, which was evidence of the rampant stigmatisation of older women, the patients fell into the first category. ${ }^{95}$ For younger women, on the other hand, a beautiful body might represent an asset; this perspective could be used to justify Dujarier's decision to operate on Geoffre, as she worked in the fashion industry, which is particularly sensitive to physical appearance. ${ }^{96}$ The second category was mainly composed of women who were unable to find a husband. ${ }^{97}$

The second argument dealt with the promotion of mental health through the aestheticisation of the body. This reflected the growing interest in psychological matters among doctors who performed cosmetic surgery. The issue of freeing an individual from prohibitive physical imperfections and the theme of mental health prevention often overlap in the discourse. The argument is that psychological problems can stem from social context: mocking and hostile reactions may contribute to 'neurasthenia'. 98 'Unsightly individuals suffer from rejection everywhere they go and gradually lose hope, becoming timid and sometimes even neurasthenic'. ${ }^{99}$ Yet these two cases must be distinguished from one another. One deals with exclusion due to how a person is perceived by others; the other is a question of inhibition owing to the individual's negative self-image.

By promoting the psychological merits of the surgical procedure, practitioners gave credit to the idea that patients could be anxious about their physical appearance, even obsessed with it. ${ }^{100}$ Contrary to psychoanalysts who consider that the body is just the canvass on which psychic problems can be inscribed, and that psychological pain can be dealt with through individualised treatment, these surgeons argued that the body could

${ }^{91} \mathrm{C}$. Claoué, 'Propos sur la chirurgie esthétique', Médecine Internationale Illustrée, juillet-août 1931, 3-10; Pleindoux, Chirurgie Esthétique, 58.

${ }^{92}$ Similarly, Raz, 'Between the Ego and the Icepick', noted that the ability to go back to work also justified resorting to lobotomy in the USA.

${ }^{93}$ Sanchez-Puyana, De la chirurgie plastique.

${ }^{94}$ Bourgoin, Les possibilités de la chirurgie esthétique, 14.

${ }^{95}$ Passot, Sculpteur de visages; sébileau, 'chirurgie cosmétique'.

${ }^{96}$ Surgeons thus shed light on women's employment during the interwar period. Even if their point of view is that of a social elite, their positive view of women in employment (quite uncommon at the time) is re- stricted to occupations that are considered 'naturally' feminine.

${ }^{97}$ Some surgeons even ascribed some measure of social import to their surgeries: by helping women find a husband, they were supporting pro-birth policies and boosting the birth rate; see R. Sian, France Between the Wars, Gender and Politics (London: Routledge, 1996). See for instance sébileau, 'chirurgie cosmétique', 933; pleindoux, chirurgie esthétique, 58.

${ }^{98}$ This term is often used to cover symptoms such as trouble falling asleep, anxiety, nervous prostration due to an overworked nervous system or even mental or moral exhaustion. See Sanchez-Puyana, De la chirurgie plastique, 32.

${ }^{99}$ Reinoso, Considérations générales, 24.

${ }^{100}$ Vigarello, Histoire de la beauté. 
constitute the root cause of the patient's suffering, and that transforming the patient's body might be the only way to eliminate that pain. The widespread circulation of psychological studies during the first half of the twentieth century which dealt with ideas such as 'inferiority complex' and 'mental anguish' lent weight to these surgeons' arguments. $^{101}$

Often practitioners with no training in psychology diagnosed patients with neurasthenia and linked the problem to physical imperfections based solely on a list of symptoms indicating lethargy and slackness. The risk of suicide was frequently mentioned, thus serving as a tragic reminder of the danger of underestimating suffering. ${ }^{102}$ Concerns about unsightly physical defects were framed as obsessive, which, in turn, was described as a uniquely feminine trait, as women were seen as naturally more vulnerable to psychological troubles than their male counterparts. ${ }^{103}$ It was advanced that women who fell prey to their emotions and desires would become uncontrollable, and that the psychological sciences, suddenly powerless to help these individuals, should then give way to cosmetic procedures.

Some women are racked with despair for a defect that seems to us of so little importance that we are first inclined to believe they are hypochondriacs. ... We can do great service to these women whose psyche is disturbed by correcting the physical defect. In such cases, the operation's psychical outcome is even more positive than the cosmetic results. ${ }^{104}$

This statement mirrors gynaecological interests which, since the end of the nineteenth century, have considered the psychological and biological dimensions of the individual jointly, favouring an organist view of the body. ${ }^{105}$ Lacking legitimate knowledge of the psychological sciences, these practitioners freely combined somatic and psychodynamic perspectives in a pragmatic, simplified approach to diagnosing patients.

The arguments defending the physiological benefits of cosmetic surgery will only be briefly mentioned here, as they were marginal and no longer visible by the beginning of the 1930s. This physiological approach focuses on the supposed link between an organ's appearance and its ability to function correctly. It was posited that the way a breast looked was correlated to its physiological and endocrinal efficacy, or even to that of the woman's entire body. This reasoning was put forward during the same period that Leriche was advocating a primarily physiological approach to surgery; the scalpel, it was argued, should be used to normalise or restore bodily functions, such as glandular secretions, rather than being utilized uniquely for ablations. In this view, the illness is due to hormonal disorders rather than anatomical lesions. Physiology, immunology and the budding field of endocrinology were all based on systemic perspectives, which assumed the

${ }^{101}$ D. Linehan and P. Gruffudd, 'Bodies and souls: psycho-geographical collisions in the south wales coalfield, 1926-1939', Journal of Historical Geography, 2001, 27, 377-94.

${ }^{102} \mathrm{M}$. Grodzki, 'Fautes techniques et danger dans la chirurgie plastique du sein', Revue de chirurgie structive, 1935, 5, 39-58; Bourguet, Correction Esthétique.
${ }^{103} \mathrm{O}$. Moscucci, The Science of Woman, Gynecology and Gender in England, 1800-1929 (Cambridge: Cambridge University Press, 1993); Oudshoorn, 'United We Stand'.

${ }^{104}$ Sanchez-Puyana, De la chirurgie plastique, 48.

${ }^{105}$ Moscucci, The Science of Woman. 
interconnectedness of organs and systems, or even of organs, sexual orientation and the psyche. $^{106}$

The shape of the breasts was seen as an indicator of the patient's overall health, and unsightly breasts were understood to be a visible symptom of an internal health issue. ${ }^{107}$ Some practitioners took this logic a step further, reversing the alleged causal relationship between the beauty of an organ and its ability to function properly; they asserted that the morphological improvement of an organ could enhance its performance and could even have a salutary effect on other bodily functions (lactation, menstruation or pregnancy). This view assumes the existence of a specific interconnectedness of systems which is proper to the female body. ${ }^{108}$ Passot stated, 'by straightening the breast, you return its esthetic value, and its glandular value as well'. ${ }^{109}$ Noël mentioned 'a case that was equally strange and interesting' of a woman who looked quite masculine and was suffering from amenorrhea and trichosis. ${ }^{110}$ After having undergone three breast operations, the patient's menstruations reappeared, she looked more feminine and, even more surprisingly, she was finally able to conceive. Thus, a woman's health was closely associated to her beauty and her reproductive abilities. This discourse is a reminder of the special interest the medical world takes in the female body; these assertions served to reinforce the gender roles traditionally ascribed to women. ${ }^{111}$ Beyond the link between shape and function, Passot daringly hypothesized that an a esthetic improvement could trigger endocrinal changes that would in turn affect the patient's humour: 'I am convinced that the famous "mood transformations of the women who have undergone surgery" are not due to any psychological cause ..., as it is commonly believed, but that their cause is of a physiological nature, resulting from endocrine stimulation'. ${ }^{112}$

These three different arguments coexisted, and the same surgeon sometimes championed all three. This indicates that multiple ways of understanding and defending the practice of cosmetic surgery were gaining ground, even though the argument for 'allowing individuals to live normal lives' remained predominant in the discourse. Over time, these lines of reasoning were largely replaced by the promotion and approbation of personal achievement. ${ }^{113}$ The early lack of unity, however, may simply be considered a bump in the road toward the creation of a new medical world. Early on, there was no talk of a new field; the focus was on legitimising a novel way of conceptualising and conducting a new practice. ${ }^{114}$ This discussion was crucial for the establishment of cosmetic surgery, as it was a necessary step in defining the practice's medical identity.

${ }^{106} \mathrm{~L}$. Dartigues, 'Greffe et inversion sexuelle', Le Concours Médical, 13 mai 1928, 50, 1464-7.

${ }^{107}$ Montant and Dubois, Chirurgie plastique des seins (Paris: Editions Maloine, 1933), 6.

${ }^{108} \mathrm{~A}$. Espaillat, 'Contribution à l'étude radiographique du sein normal et pathologique', Unpublished medical PhD, Paris, 1933.

${ }^{109}$ Passot, Sculpteur de visage, 213.

${ }^{110} \mathrm{~S}$. Noël, 'Rapport des opérations esthétiques des seins avec les glandes ovariennes et mammaires', Le Bulletin Médical, 1934, 48, 611-13.

${ }^{111} \mathrm{~T}$. Lacqueur, Making Sex: Body and Gender from the Greeks to Freud (Cambridge, MA: Harvard University Press, 1990).
${ }^{112} \mathrm{R}$. Passot, 'Atrophie mammaire: réfection esthétique par la greffe graisseuse et épiploique', La presse médicale, 7 mai 1930, 37, 627-8, 628.

${ }^{113}$ Barbot and Cailbault, 'Figures des victimes'.

${ }^{114}$ This issue will arise in the mid-1930s. See, for example, M. Coelst, 'Discours du Dr Coelst, président, Compte rendu du premier congrès international de chirurgie structive, 3-4 octobre 1936', Revue de Chirurgie Structive, 1936, 5, 337-42; J. F. S. Esser, 'Discours du Dr Esser, président d'honneur', Revue de Chirurgie Structive, 1936, 5, 343-5. 


\section{Conclusion}

Dujarier was supported by various groups and for various reasons, ranging from the defence of cosmetic procedures to professional self-regulation. In addition to the surgeons who saw Dujarier's trials as their first opportunity to publicly defend their cosmetic surgery, other practitioners with broader professional horizons used Dujarier's initial case and its appeal to highlight and condemn the difficulties they encountered practising medicine. The main rallying cry was that their profession was in crisis; that Dujarier's renown did not protect him from professional undoing exposed the extremity of the situation.

This article does not attempt to understand the basis of cosmetic surgery merely by examining the positions that practitioners who performed cosmetic procedures held in university hospital hierarchies. ${ }^{115}$ This is simply because, while these hierarchies officially recognise the achievements of high-ranking practitioners, they cannot provide de facto legitimacy to these doctors and their practices. Indeed, many doctors involved in cosmetic surgery were marginalised. We have chosen, therefore, to examine the way in which doctors involved in cosmetic surgery brought meaning to their own activity as well as the impact of the legal system on the evolution of that meaning.

Dujarier's successive trials, combined with the massive response they provoked, helped to reinforce the distinction between reconstructive and cosmetic surgery and to highlight the latter's specificities. Moreover, the legal status of cosmetic surgery defies precise definition even today. The practice only appears to be authorised under very strict conditions, as attested by the endless list of trials that continue up to the present. This special status is partly a result of the difficulties advocates have had in demonstrating the therapeutic merit of cosmetic surgery, and partly due to high social expectations and the particularities of the specialty's distinct professional practices. The law of 4 March 2004 increased the surgeon's responsibility to fully inform the patient, and a specific tax on cosmetic procedures was even under discussion in September 2012. In the end, the period of mobilisation that occurred between the First and Second World Wars proved a lost opportunity for doctors involved in cosmetic surgery to mount a united front in defence of the practice's procedures, objectives and raison d'être. ${ }^{116}$

Finally, attention must be paid to the fact that when these surgeons were defending their practice they relied heavily on pre-existing realities. Kuhn urges us to consider how difficult communication can be when paradigmatic shifts occur, and to study the way innovators create new language that unites groups of people. ${ }^{117}$ In France, these new ways of conceptualising cosmetic surgery rested on pre-existing perceptions and attitudes in society (the importance of beauty in social and professional success, the development of the concept of 'psyche', the nature or essence of women, etc.). Far from proposing a paradigm shift, as Haiken suggests occurred in the United States, these practitioners clung to the age-old ideals of the medical community, and rehashed old arguments in an effort to legitimise their practice. ${ }^{118}$

${ }^{115}$ Guirimand, 'Naissance de la chirurgie esthétique en France'.

${ }^{116}$ Y. Le Hénaff, 'L'entreprise morale en chirurgie esthétique, un mandat aux marges de la médecine', Unpubished PhD, Rennes 2, 2010.

\footnotetext{
${ }^{117} \mathrm{~T}$. Kuhn, The Structure of Scientific Revolutions (Chicago: University Chicago Press, 1962).

${ }^{118}$ Haiken, Venus Envy.
} 
As is often in the case with mobilisations, these two trials fostered dialogue between isolated parties, practitioners who worked outside hospital institutions and came to discover a new social world. This common cause led to the creation of the short-lived Société Scientifique Française de Chirurgie Réparatrice, Plastique et Esthétique in April 1930. The Dujarier trials, especially the first, jump-started the debate which eventually led to the establishment of a new specialty. The case has since provided common reference for doctors involved in cosmetic surgery. This, in turn, gave birth to a network with its own 'scientific' tools (professional journals, technology, conferences, methods, etc.) which allowed doctors performing cosmetic surgery to showcase their specialty and contributed to strengthening the bonds among the members of a social world that remained loosely defined. These tools provided opportunities for practitioners to connect and reinforce their professional identities, through the articulation of various identity markers such as a feeling of being marginalised, a fear of legal problems, a denouncement of external regulation and discussions about therapeutic arguments for cosmetic surgery and how to approach the doctor-patient relationship.

\section{Acknowledgements}

I am especially grateful to Julien Fuchs, Julie Loret and Thierry Pillon for their useful readings of various versions of this manuscript. 